\title{
Islamophobia, Othering and the Sense of Loss: Leila Aboulela's The Kindness of Enemies
}

\section{Khaled Abkar Alkodimi}

Department of English Language and Literature, College of Languages and Translation Al-Imam Mohammad Ibn Saud Islamic University

Saudi Arabia

Email:kaq2002@yahoo.com

Received: 11/10/2020

Accepted: 2/1/2021

Published: 2/24/2021

\begin{abstract}
Muslims' image in the West had completely changed since 9/11,2001. This paper uses the textual analysis method to explore Leila Aboulela as a writer with a sophisticated commitment to Islam who strives to counteract the biased perception of Islam and Muslims. Drawing on the views of Wail Hassan, the study focuses on Leila Aboulela's novel The Kindness of Enemie to examine the author's concern of Muslims' image in the west after the 9/11 terrorist attack and its impact on Muslims, particularly the immigrants. It argues that Aboulela uses Imam Shamil as a metaphor to debunk the terrorist attacks that target innocent people under the pretext of Islam, and on the other hand, setting a good example of the concept of jihad. The findings show that Aboulela's primary concern is to condemn terrorist operations against innocent people worldwide. To illustrate her views, the author uses two contrasted pictures, the historical story of Imam Shamil, who embodies the proper jihadist/resistance vis-à-vis with the current so-called jihadists. The study further shows that those terrorist acts have significantly impacted Muslims' lives and are the first cause of contemporary racism, islamophobia, and the sense of loss among Muslim immigrants in the west.

Key Words: islamophobia, Leila Aboulela, Muslim immigrants, other, terrorist, The Kindness of Enemies

Cite as: Alkodimi, K. A. (2021). Islamophobia, Othering and the Sense of Loss: Leila Aboulela's The Kindness of Enemies. Arab World English Journal for Translation \& Literary Studies 5 (1) 144-158. DOI: http://dx.doi.org/10.24093/awejtls/vol5no1.10
\end{abstract}




\section{Introduction}

Leila Aboulela, born in 1964, is an acclaimed Arab-British novelist born in Cairo but raised in Sudan, a country that she frequently revisits in most of her literary oeuvre. As a successful craftswoman, bestowed with great creative skills, Aboulela draws the attention of critics and researchers from different parts of the world who showed a keen interest in her works, which focuses on a variety of sociopolitical issues like identity, immigration, racism, Islamophobia, Islam, and assimilation. Such common recurrent themes in her works paved the way for Aboulela to become a global literary figure. What is peculiar about her, is that she becomes a committed Muslim novelist whose "fiction as a whole depicts the experience of practicing Muslims in Scotland and England, from a narrative perspective committed to an Islamic world view..." (Hassan 2011, p. 180). In other words, she became a "devout Muslim and show more commitment to the teachings of Islam in search of inner peace" (Flicker, 2020). Hassan, (2015) further claims that Aboulela's work "embodies the slogan of the Islamist movement that emerged in the mid1970s: Islam is the solution" (p. 183). In this sense, she appears to prefer realism as a strategy to portray the struggle of Muslims in the west. Abolela openly admits this view when she said, "I do not tend to experiment in writing, and I believe that the reality of these challenges requires us to be accurate when describing them. This is particularly because the school of realism has always been dominant when it comes to novels" (Flicker, 2020). According to Flicker, many critics think that Aboulela appears to introduce a different image of Muslims through the female characters in her novels who find shelter and cure in religion, rather than escaping it. Perhaps, this is why Mike Philips, a British critic considers Aboulela as one of the most important writers in a new type of English narrative fiction, contributing to a wide range of Islamic novels (Flicker, 2020).

In general, nobody can deny the great storytelling talents of Aboulela. According to Jamal Mohammed Ibrahim, she has made a breakthrough for Sudanese writing and creativity and has had an impact similar to that of late Tayeb Saleh where religion and alienation are the central topics in most of Aboulela's literary works (Flicker, 2020).

\section{Methodological Framework}

This paper applies the textual analysis method to examine Aboulela's novel, The Kindness of Enemie(2015). The textual analysis method is simply an approaoch that can be applied to analyze the content and the messages contained in a particular text (Botan, 1999). By applying this methods, the researcher intends to explicate the deeper meaning and hidden messages of the selected text. The study argues that Aboulela has skillfully utilized the historical Muslim figure of Imam Shamil as a metaphor to highlight the changing image of Muslims in Britain and to debunk the current terrorist attacks which could be the main reason of such distorted image. It draws on Wail Hassan and others' work to explore Leila Aboulela as a novelist whose work is engaged in Islam and spirituality and who is considered a robust Muslim voice that opts to reform the distorted image of Muslims. Hassan (2011), for instance, describes Aboulela's fiction as a work that "represents a linguistic and ideological departure from Arabic fiction, and a new dimension in Anglophone immigrant and postcolonial literature", considering Aboulela as an author 
"committed to an Islamic world view". He further states that her works "undertake to explain Islamic theology, shari'a, and rituals to Muslim and non-Muslim readers" (p. 192). In his view, Aboulela's work "represents two historical developments since the 1970s: the Islamic resurgence that has attempted to fill the void left by the failure of Arab secular ideologies of modernity, and the growth of immigrant Muslim minorities" in the west (p. 181). Khalifa, (2011) also notes that "in their quest for their Muslim identity, many Muslim women writers create a counter-discourse of themselves and Islam through fiction writing $(2011$, p. 2). Khalifa further points out that "these writers struggle to write back from a strategic positioning where they reclaim their Islamic cultural and religious identity as a mode of discourse that enables them to write back to the stereotyping center in the west (p. 6). Khalifa's view has been emphasized by Al-Karawi (2014) who notes that "the continuous attack on Arabs and Muslims after 9/11 has generated the need to locate and create space through which Arab immigrant women can speak" (p. 257).

\section{Literature Review}

\subsection{Aboulela, the novelist}

As a writer of fiction, Aboulela's debut novel is The Translator. This beautifly crafted story deals with the romantic affairs of Sammar, a young Sudanese widow living in Britain and a Scottish scholar specializing in Arab and Islamic studies. As the story progresses, Samar demanded her lover to convert to Islam so that they could get married. This novel, according to Wail Hassan "offers a critique not only on racism and Islamophobia but also of nativism, liberalism, multiculturalism ..." (2011, p. 188). Mahmoud Khalifa also states that "Aboulela's The Translator is a reflection of a strong nostalgia to memories of home and the associated Islamic rhythm. For living as an immigrant makes it hard to follow the Islamic rhythm", as the case with Samar, the heroine of Aboulela's The Translator and the heroine of Mohja Kahf's novel, the Girl in the Tangerine Scarf (Khalifa, p. 57). According to Khalifa, these characters are "engaged in a struggle to define their Muslim identity in a culture that is hostile to their beliefs and cultural heritage". Samar, for instance, "finds in prayer a form of support in a world of existential insecurity and a giver of identity" (Khalifa 38, p. 57).

Similarly, Aboulela's subsequent novel, The Minaret (2005), tells the story of Najwa, a Sudanese refugee girl in Britain who suffered from a harsh life in exile and alienation from her homeland and culture. Najwa moves to London where she meets Anwar, a socialist student she previously met in Sudan. Unexpectedly, Najwa, starts to imitate western life styles, leading a free life in London. She freely goes to night clubs and puts on revealing clothes. "The party at the American club was in full swing when Omar and I arrived. We walked into the tease of red and blue discount lights and the Gap Bandages 'Say Oops Upside Your Head'...'My trousers are too tight'. An awkward twisting around to see my hips in the mirror", Najwa said (Minaret, p. 25). Significantly, however, Najwa "has undergone an Islamic and spiritual awakening that separates her from her previous life in Sudan, as well as from her previous self as the daughter of a corrupt politician-businessman" (Al-Karawi, p. 258). Islam, according to Khalifa, "gives meaning to her life and solace in this precarious world" (p. 63). For Al-Karawi, Minaret de Leila Aboulela allows 
readers to look at the forms in which the veil represents a sign or a stereotype whose diversity is not understood until it unpacks the living conditions of the Arab Muslim woman in the west (p. 255). Mahmudul Hasan also notes that Minaret and Love in Headscarf may be considered as two basic pillars of universe "Islamic Literature" by Muslim women. (p.96). Interestingly, both The Translator and Minaret "portray characters whose Islamic beliefs greatly influence their perceptions about their identities and largely regulate their relationships with other characters and the societies in which they live" (Awad, p. 70).

Such development in fiction became inevitable in Hasan's (2015) view "after 9-11 and 77 as Muslim women's stereotypic portrayals hit new heights of vulnerability and opacity, claiming that Muslim authors have long been compelled to render Muslim women with a disordered western vision" (p. 93). In this sense, Aboulela appears to be one of those female writers who attempt to "redefine and reposition Islam in relation to women's lives and struggles and describe the religion as a living system and an integral, inseparable part of who they are" (Mahmudul Hasan, p. 94). For Hasan, Aboulela and Janmohamed are both religious and contemporary writers, committed to combating the misunderstandings of Islam and Muslim women (p. 94).

Interestingly, history seems to be the backdrop on which Aboulela establishes her views. Benguesmia and Refice (2019) note that Leila Aboulela is "inspired by a set of historical events and experiences" (p. 18). In an interview, Aboulela mentioned that writing a historical novel is a challenging task as she had to rely on actual events and stories. According to Benguesmia, The Translator (1999), and Minaret (2005) are two "public fictional novels by Leila Aboulela, in which she exposes several historical events that she has witnessed, lived or at least been told" (p.19). For instance, her literary works "marked by narrative, descriptive, and linguistic images" that reflect Sudan's history and culture (Flicker, 2020). Such tendency can be dicerned in her "history-based novel Lyrics Alley, in which Aboulela seems to be "inspired by the biography of well-known Sudanese poet Hasan Aboulela (1922 - 1962), in a compelling mix of autobiography literature and fiction" (Flicker, 2020).

However, as one of the diasporic Muslims, Aboulela's fiction does not only reflect historical events but more importantly functions history to tackle specific issues like Muslim identity and religious faith, bringing a new perspective about Muslims and Islam stereotyping in western societies. This shows that Aboulela "succeeded at depicting reality behind the stereotypes of Muslim immigrants' identity and beliefs" (Benguesmia, p. 19). As Wail Hassan points out, the "west of Aboulela is philosophical and behavioral: it is marked by the anti-Islamic and hostility against Muslims in every region and location, irrespective of color, language, tradition, nationality or geography" (p. 182).

\subsection{The Kindness of Enemies: Synopsis}

Like her previous novels, Aboulela's The Kindness of Enemies (2015) is based on real historical events. However, the story runs two stories in parallel. Presently, Natasha Hussein of a Sudanese father and Russian mother is a university scholar specializing in Russian imperialism 
and jihad as a form of resistance against the Russians' invasion in Dagestan, Chechnya, and Circassia in the 19th century. Natasha learns that Oz has an interesting item, the sword of Imam Shamil, his ancestor and the leader of the Caucasian Muslim Rebellion against Russian attacks. She visits him and stays with him and his mother for a couple of days. In an early morning search, during her visit, Oz is abruptly arrested by security forces from his mother's home, being suspected of having connections with terrorist groups. This incident has affected all thouse around $\mathrm{Oz}$ including Malak and Natasha. This story is paralled with the story of Imam Shamil whose army was besieged for eighty days in 1839 and Shamil handed over his eight-year-old son, Jamaleldin as a Russian hostage, to escape poverty. Fifteen years later, Imam attempted to save his son. Princess Anna Georgia and her son were kidnapped and imprisoned in exchange for the liberation of Jamaleldin.

However, the issue at stake is that this novel offers a sharp critique of the Islamophbia phenomenon that had swept through most of the western communities due to the changing image of muslims in the west. In his research, Erik Bleich concludes that "islamophobia can best be understood as indiscriminate negative attitudes or emotions directed at Islam or Muslims. ... where negative assessments are applied to all or most Muslims or aspects of Islam" (2012, p. 181). This study attempts to shed light on Abuolela's main concern in this novel, The Kindness of Enemies.

\section{Aboulela's The Kindness of Enemies: Post 9/11 and the Distorted Image of Muslims in the West}

Indeed, Muslims' image in the west had fundamentally changed since 9/11. Benguesmia and Refice, (2019) had succinctly summed up the situation as they note,

precisely after the 9/11 attacks, the image of Islam has changed, and Muslims were greatly affected by these events, especially those living in western countries, on the aftermath of the events, many of them suffered discrimination, racism, violence as well as a stereotype. Islam became associated with terrorism and Muslims were treated like extremists and criminals (p. 25)

Raina also observes that since "9/11 the media has been full of images of the Middle East and Muslims, many of which have reinforced stereotypes about Muslim people, their beliefs, and ways of life" (2009, p. 14). Furthermore, in his paper, Examining the Critical Role American Popular Film Continues to Play in Maintaining the Muslim Terrorist Image, Post 9/11, Rubina Ramji argued that "Immigrant Muslims in America have become demonized as a national security threat since 9/11". This "demonization and otherness", according to him, has existed for a long time as "muslim communities and families face bias crimes, sweeping arrests, popular and media hostility and official assumptions of 'guilt by association'. For decades, the West has viewed Islam as violent, confrontational, and barbaric" $(2015$, p. 1). According to Ramji, many Americans turned to popular media chanells to know more about "Islam and the terrorist motivations of these 
Muslims, [however], instead of illustrating a highly diversified Islam, these outlets seemed to merely confirm the existing stereotypes" (p. 9).

However, the objective of this paper is not to delve into the representation of Muslims in the western media but rather to textually analyze how Aboulela has functioned her novel to depict the consequences of the changing image of Muslim immigrants in those communities. Interestingly, Leila Aboulela's The Kindness of Enemies seems to be very much concerned with Muslims' situation in the west. Broadly speaking, however, most of Aboulela's novels attempt in one way or another, to illustrate the life of Muslims in the west after the 9/11 terrorist attack. At the same time, she seems to advocate Islamic spirituality to achieve tranquiltity and peace in life. In other words, Aboulela's works have "celebrated ethnic and cultural mixing they have also promoted Islamic practices and advocated Muslim immigrants' religious freedom in the West" (Benguesmia, p. 31). Her recent novel, The Kindness of Enemies, offers a bitter critique of the current situation of Muslims in the west in general and Britain, in particular. Her views are mostly illustrated through the major characters, Natasha, Malak, and Oz, who appear to enjoy a normal life at the beginning of the story, however, everything has changed after Oz's arrest and imprisonment in spite of his release without charges.

The changing circumstances of those characters began with Oz's arrest whose story is used as a scapegoat to comment on the lives of Muslims there. Natasha's description of Oz's sudden arrest illustrates the awkwardness of the situation as time stood still and everyone is speechless. "Because the front door had been open all the time the police were here ..., Natasha said. 'It's a mistake', his mother repeats. They've mixed him up with someone else, I'm sure"' (p. 79). Obviously, Oz's story has been carefully functioned in order to highlight the image of Muslims in the west, a terrorist that should be 'monitored' (p. 147). Richardson (2002) declares that after 9/11 attacks on New York, the American and western media "recirculate the old binaries" West and East, Christendom and Islam which speak to the "stereotypical Oriental Other" that provides filmic and literary representations of the Oriental culture (as cited in Khrisat, 2018, p. 59). Mahmudul Hasan also notes that "Orientalist tendency maintains a reductionist approach and mainly focuses on caricaturing Islam and Muslims. Some notable classical Orientalist texts ... provide distorted portrayals of Muslim societies ..." (2015, p. 89).

Indeed, Oz's story puts Aboulela's views in action, though he has been suddenly arrested and released without any charges, this incident, however, has destroyed his life. His future has been completely "ruined" and what is worse is that he becomes unable "to get out of this" (p. 185). "Oz was released yesterday. ... He's not talking to me. He's not leaving his room. He won't eat ... I don't know what to do. Can you come over? Maybe he will talk to you", said his mother to Natasha (p. 219). Hence, Oz went into a state of emotional disorder, refusing to talk to anyone including his mother. More inportantly, he decides to drop from the university and to move to south Africa. His mental and psychological disorder makes him unable to tolerate the changing situation in Britain. Unfortunately, however, all those around him have become potential suspects, 
therefore, they have to bear the burden, including his mother and Natasha. This is why his father in south Africa rejects the idea of offering hand to his son in London. "They might drag me into it and then what use would I be to him? Can you believe it!" his father said. "Yes, I could believe it", confirmed Malak, (p. 187), who is now, very much aware of the changing situation around her. As Wail Hassan notes, "prejudice and harassment by total strangers against practicing Muslims, identifiable by their ..." (p.194). He adds, "ugly incidents of racism and harassment of Muslims, particularly Muslim women wearing hijab are depicted in most of Aboulela's texts" (p.189).

Racism and otherness against Muslim immigrants is further illustrated through Natasha Hussein whose comments on the police investigation of the robbery of her house confirms the difficulties of Muslims there. "... it became more prominent than what I was saying; and I was now an impostor asking for attention, a troublesome guest taking up space. They had better things to do and worthier citizens to protect" (p.108). Her comments summed up the situation of Muslims in Britain who turned to be mere unwelcomed guests. Unfortunately, Natasha whose "dignity" was "shaken" (p. 176), realizes that the police is not concerned about her case. More importantly, their indifference reflects their negligence for her as she is considered the unwelcome 'other'. As Benguesmia and Refice (2019) note, "western media have promoted the idealization of the western values of democracy, on the other hand portrayed Islam as the religion of violence, sexism, and described it as hostile and unreasonable, and accused Muslims of terrorism" (p. 25). Mahmoud Khalifa further notes, "the representation of Islam in the west was built around a binary system that endowed Islam with negative characteristics and the west with positive characteristics". He adds, "west makes Islam one of the most recurrent images of the other in Europe and one of the most stereotyped and vilified religions ..." (p.1). Mahmudul Hasan also points out that "Muslims have been made into objects of exclusivity and of continued analysis" since the attacks on New York and London, adding that "their identity is hidden behind a smokescreen of uncertainty...". For him, "both the popular media and literature lay enormous emphasis on the religious affiliation of the perpetrators of the infamous 9/11 and 7/7 horrors". This, according to him, "rendered the Muslim residents in the west as 'exoticized others' and 'outsiders' whose presence is said to constitute a threat to the western way of life" $(2015$, p. 95). The idea of racial prejudice has been further highlighted through Gaynor's complaint against her teacher, "Natasha put her fat arse on my desk ... Black arse ... fat black arse ... 'Black arse ... fat black arse ...". However, Natasha's reaction to Gaynor's attitude shows her deep disappointment, "the words looped and steadied, they became rhythmic. I woke up warm with humiliation ...", she said (pp. 113-114). Surprisingly, Gaynor didn't take any action against another staff, she made her complaint only against Natasha, a woman of a different color and religion.

Oz's revelation to Natasha further reflects his awkward experience with the police and its effect on him. In his letter which he started with an apology, he informs her, "I'm sorry I behaved poorly that day you came over. I wasn't up to talking much and to tell you the truth, it was because what happened psyched me out. The cell felt as a small as a cupboard and ..." (pp. 298-99). Obviously, Aboulela seems to function Oz's voice as an eye witness to emphasize her vintage 
point that the life of any Muslim regardless of his position can suddenly turn upside down. What adds insult to injury and saddened Natasha even more is being helpless: "Oz had dropped out" and the news "passed around the department with relief as if we were well rid of him. One of our best students", Natasha said. She continues, "I hid myself in the ladies' and cried with anger, ashamed that, even now, I could not stand up for him" (p. 323).

Such social and political atmosphere led Muslim immigrants in the west to hide their real identities. That is to say, "many Muslims in Britain wished that no one knew they were Muslims. They would change their names if they could and dissolve into the mainstream, for it was not enough for them to openly condemn $9 / 11$ and $7 / 7, \ldots ”($ p. 6). They even feel ashamed of their parents who bear the signs of being immigrants. As Natasha declares,

Muslims I taught throughout the years couldn't wait to bury their dark, badly dressed immigrant parents who never understood what was happening around them or even took an interest, ..., who obsessed with about halal meat and arranged marriages ... They grew up reptiles plotting to silence their parents' voices, to muffle their poor accents, their miseries, their shuffling feet their lives of toil and bafflement, ... (p. 7)

Ironically, Natasha herself has erased her father's identity. She called herself Natasha Wilson instead of Hussein (p. 324). It is ridiculous that she was "ashamed to be seen with him around the campus" when he visited her in London (p. 77). However, it is the social atmosphere that leads her to behave awkwardly as she feels ashamed of standing in public with her father, who has crossed a long distance to see his daughter. According to Sardar, "modern Orientalism proceeds to rely heavily on the medieval images of Islam" confirmed by Butler (1988) that the "Orient has long fascinated British artists as an imaginary realm of luxury, violence, and sensuality" (as cited in Khrisat, p. 59).

Significantly, Oz's mother, Malak, a successful actress who honestly devoted her efforts to serve and to please the community, suddenly realizes that she is the mere 'other'. She is neglected and looked at with contempt and doubt. She realizes at the end of the day that she is a stranger, despite the services she has offered for the community. Her innocence and good deeds did not spare her. Her life has completely changed "from the optimistic activist mum campaigning for the release of her son to the shadows of being under suspicion" (p. 226). In one of her conversations with Natasha, Malak complains, "my dinner invitations drying up, even the offers of roles dwindling ever so slowly without knowing exactly why. ..." (p. 226). Regretfully, Malak who previously rejects any complaints by Muslims in Britain, ultimately finds herself neglected and, like her son $\mathrm{Oz}$, experiences a psychological state. The conversation between her and Natasha clearly describes her current state when Natasha tried hard to help her to overcome the situation: "I think you are unduly pessimistic, Natasha Said. However, Malak's reply fully summmed up her new situation, "all my life I have been hugely optimistic. I have gone ahead with loads of energy, loads of goodwill, until now. I am stumped. I stay up at night ...” (p. 226). Such pessimistic reply 
reflects the negative impact of the situation on her life. Her optimistic view of life has utterly vanished.

Like many of Aboulela's characters, Malak ultimately escapes to religion as she finds solace in spirituality, trying to overcome the sudden shift in her life. Her religious tendency has been manifested in the attendance of several Islamic ceremonies to which she has invited Natasha Hussein who appears to be less interested in such Muslim gatherings. These "Muslim gatherings in the mosque create an alternative space for immigrant Muslim women" (Khalifa, p. 67). According to Khalifa, these characters are "engaged in a struggle to define their Muslim identity in a culture that is hostile to their beliefs and cultural heritage. ... They find redemption in reclaiming their Muslim identity" (p. 38). Hence, Aboulela seems to stress such spirituality among her characters as most of her characters escape to religion as a solution to overcome life's difficulties.

Like Malak, Natasha too ultimately realizes that she is strange although she has been a successful academician at the university where she has been teaching for a long period of time. Natasha's comments on her changing situation clearly depicts her disappointment:

Every step climbed, every achievement, every recognition-all that hard work- had not taken me far enough, not truly redeemed me, not landed me on the safest shore. The skin on my skull tensed so that I could not form a facial expression; even pushing my glasses up my nose felt strange... To have your files examined, to reveal what is exceedingly intimate- a password and a search engine history- felt hundred times worse ... (p. 175)

Hence, Natasha's office was examined. She was also questioned about her relationship with Oz, her student and whom she once visited at home to learn more about Imam Shamil, the subject of her academic research papers. Perhaps, this is why she admits that her "dignity [was] shaken and [her] balance broke" (p. 176). She openly declares:

I was actually one of the lucky ones. I was one of the ones who saw the signs early on in the tricksy ways of schoolchildren, in the way my mother, snow-white as she was, was disliked for being Russian. I saw the writing on the wall and I was not too proud to take a short-cut to the exit. (p. 7)

Unlike Malak, however, instead of escaping to spirituality, Natasha seems to resist religiosity from the beginning of her life there. However, as Khalifa notes, "this insistence that Muslim women deny their religious identity in order to fit in, is a fundamental issue that these novelists raise and discuss" (p. 7). Yet, dispite all she did to fit in, unfortunately she never felt at home. Instead, she has been treated as the 'other'. Interestingly, her identity crisis in Britain provokes her feelings towards Sudan and the people there as she feels home nostalgic. 
Such sense of loss was shared by the three characters, Natasha, Oz and Malak whose stories had been skillfully yoked together to produce a clear image of Muslims' lives in Britain after 9/11. According to Edward said, Muslims "where ever they may be settled, are viewed through a certain lens" (as cited in Raina, 2009, P. 23). Said's view is confirmed by Janmohamed, who provided a list of labels that are generally attached to Muslims, particularly women: "Oppressed, repressed, subjugated, backward, ignorant Violent, extremist, hateful, terrorist, jihadist, evil, radical Weakling, moderate, sellout, self-hating, apologist” (Mahmudul Hasan, pp. 92-3).

Obviously, "the sweeping, Islamophobic and racist tendency of the host white society adds one extra layer of oppression on them" (Mahmudul Hasan, p. 99). The situation of the three characters, for instance, was summed up in Natasha's words when she admits, “... it now took conscious effort to walk with my head held high. My voice became softer, my opinions muted, my actions tentative. I thought before I spoke, became wary of my students and, often bowed my head down" (p. 324). Thus, it is ridiculous that even though she has changed her father's name in order to fit in, she ultimately realizes that she would never belong. Unfortunately, although she is an accomplished and a successful academician, Natasha struggles with a deep "sense of disconnect and duality about her identity and place. Born Natasha Hussein, she changes her name to Natasha Wilson to try to blend in to a place where neither of her parents felt at home" (Carroll, 2016).

In contrast, though she grows up outside Sudan, Natasha feels comfortable as soon as she arrives and meets people there. She immediately feels a sense of belonging, as she remarks,

Chatting with them, we would skip from Russia to English to Arabic, and I relaxed without proving, explaining, or distinguishing myself. Nor squeeze to fit in, nor watch out of the corner of my eye the threats that my very existence could provoke in the wrong place in the wrong time among the wrong crowd. (p. 324)

Obviously, the very mention of the word 'to fit in' sums up the whole idea of belonging. Like Malak, despite the accompishments she achieved, she feels strange. Both Malak and Natasha achieved fame, success and served the public to the best. However, by the time they feel that they are part of it, unfortunately that community seems to reject them, hence, the sense of loss and humiliation had replaced the sense of belonging and connection to that community.

\section{Resistance, Jihad, Terrorism: Imam Shamil as a Metaphor to Illustrate the Mystery of All}

A part from the image of Muslims that Aboulela attempted to highlight, another central idea in Aboulela's The Kindness of Enemies is to set a good example of Jihad as this concept has become synonymous with terrorism. In this regard, she introduced a live picture of the historical figure Imam Shamil who led the resistance against the Russian emperor in the Caucasus early $19^{\text {th }}$ century. According to her, Imam Shamil embodied the real example of jihad as his resistance is justified since Imam Shamil and his people got, in Slater's words, a "just cause", (as cited in Alkodimi 2019, p.136) to defend their homeland against the Russian invasion. In contrast, the 
suicide bombers by al-Qaeda members and other militant groups are considered anti-jihadists or terrorists. They misinterpreted the essence of Islam in general and the concept of jihad, in particular. According to Aboulela, these operations defamed the image of Islam and Muslims. This idea was made clear as early as the first few pages of Aboulela's novel. Malak's comments, "ever since 9/11, jihad has become synonymous with terrorism" unveils the author's dilemma, for Aboulela "jihad is an internal and spiritual struggle" (p. 9). Indeed, the misconception of jihad and the terrorist attacks under its name seem to be Aboulela's main obsession in The Kindness of Enemies. She believes that the real jihad is to struggle to be spiritually connected to God rather than committing suicides.

Aboulela wisely related Islamophobia, racism and the distorted image of Muslims in the west, discussed above, to the terrorist attacks by al-Qaeda members and other militant groups. The author succinctly but indirectly puts it that these are mere terrorists acts and have nothing to do with Islam and Muslims. On the contrary, it affected Muslims across the world and had negatively impacted Muslims in general and Muslim immigrants, in particular. Sush situation was embodied in a character in Kia Abdullah's Life, Love and Assimilation that recounts how the stigma infects their view of the world, pushing Muslims to the margins:

9/11 was not good publicity for Muslims. It created a palpable tension between us and the rest of the world. I know that there is general animosity between Asians of different religions but I had never felt it. To me we were all Asians in a predominantly white country and we stuck together. 9/11 changed all that. Sikhs and Hindus became sick of being banded together with Muslims. (as cited in Ancellin, 2009, p. 5)

As Randa Abdel-Fattah, the Australian author of Palestinian-Egyptian parentage also observes that in the post 9/11 period of media and public obsession with Islam and Muslims "most intelligent people can see past the demonic and one-dimensional images of Muslims and are thirsting for an insight into the Muslim community" (as cited in Mahmudul Hasan, p. 93).

Interestingly, Aboulela carefully utilized the historical story of Imam Shamil who leads the resistance war against the Russian invasion on Caucasus as a metaphor to deliver her views on the actual meaning of jihad. That is to say, the story of Imam Shamil had been functioned in such a way as to give a clear example of this concept. According to the author, jihad in Arabic means resistance which is very much exemplified in Imam Shamil. Through the metaphor of his figure, Aboulela strongly mocks the so-called jihadists who target innocent people including Muslims. She uses Imam Shamil to showcase the misconception of the meaning of this concept. For her jihad is resistance rather than killing innocent people and children, which leads to stereotyping Muslims as terrorists and which also gave rise to the islamophobia phenomenon. As Dunia Alzubaidi notes, "With growing pressure on UK professionals [like Natasha] to report signs of religious extremism", The Kindness of Enemies by Leila Aboulela is well timed, "drawing a parallel between the jihad perpetrated by the Islamic State (ISIS) and a case of 19th-century Sufi 
jihad in Russia". Speaking at Bare Lit Festival in London, Aboulela "contrasted the two types of jihad" (Leila Aboulela, 2016). Interestingly, that comparison is the essence of Aboulela's selected novel.

Indeed, as a craftswoman, Aboulela skillfully provided two opposed pictures in order to illustrate her views. The first portrait sheds light on the life and resistance of Imam Shamil who used Jihad to defend his land and people against the Russian invasion, and the second one describes the contemporary terrorist attacks against innocent civilians. Such live image of the two portraits vividly depicts the sharp contrast between the two situations. For Aboulela, Shamil and his men "are generous defenders of liberty against the brutal forces of the Russian empire" (p. 8). Such sharp attitude towards imam Shamil and his men is projected mostly through Malak. However, Natasha's remark on Queen Victoria's support for Imam Shamil provokes Malak, "who made a face at her son. Queen Victoria championed a jihad [?]". Oz's reaction to Malak's comments further emphasize Aboulela's views of the concept: "Don't be naive, Malak. If Russia took over the Caucasus, it would have threatened India. Besides, the word 'jihad' then didn't have the same connotation it has now" (p. 9). Interestingly, Oz's comments take us to the heart of the matter that the dilemma of the author in this story is to highlight the misconception of jihad/resistance, as "when Imam Shamil, an honorable, even noble, character uses the term, he is describing the defense of his homeland, not aggression or acts of terror" (Braithwaite, 2017).

Aboulela goes further and showed to what extent those jihadists like Imam Shamil were kind to innocent people even though they wer their enemies. The story of Anna the princess of Georgia who had been kidnaped by Shamil's men (pp. 88-90) was functioned in such way as to reflect that Shamil fights only the soldiers who had attacked his land and people. Princess Anna lived as a guest at his house. She was treated as a princess but not as a prisoner. Her story, in other words, shows the kindness of the real jihadist who fought against real enemies, their war had nothing to do with the killing of innocent people. For Aboulela, they are but 'the defenders of liberty against the brutal forces of the Russian empire' (Aboulela, 2015). Indeed, the title of the story 'the kindness of enemies' is used as a symbol to mock the current militant groups who target the innocent people. The author seems to suggest that Imam Shamil who exemplified the honest jihadist had been kind enough even to his enemies and the story of Anna, the princess of Georgia was functioned in this direction.

Malak, who is a descendent of Imam Shamil, admits and feels proud of her heritage. Speaking about her son, she tells Natasha that "he has- as I have - a heritage which is moral, and thoughtful and merciful" (p.185). According to Malak, that rich heritage does not exist in those militant groups who "are acting in the name of Islam and at the same time don't follow the principles of submission and restraints?" (p.185). Those so-called jihadists, according to Malak, are the real threat against Muslims themselves. She, on the other hand, reconfirms, through the image of Imam Shamil, the proper example of a jihadist.

Arab World English Journal for Translation \& Literary Studies 
Every fight Shamil fought was on the defence. He was protecting his villages against Russian attack. And surrender to the Russians would have meant the end of their traditional way of life, the end of Islam in Dagestan. The Russians were so brutal they often didn't take prisoners of war (pp. 9-10)

Yet, Aboulela's intention seems to be briefly confirmed when Malak declares that "by comparison Shamil's generals were scholarly and disciplined" (p.10).

Indeed, Aboulela's intention had been revealed as early as the first few pages of her story. She made it clear that her main concern is to debunk the current terrorist attacks under Islam's pretext. Such view is mostly carried over through the major characters. For instance, the hot argument, referred to above, between $\mathrm{Oz}$, Malak and Natasha, made it clear that there is a misconception of the meaning of jihad nowadays. Malak sums up the idea of the author when she concludes the above discussion by saying, "This type of jihad [Shamil's] is different from the horrible crimes of al-Qaeda" (p.10). Using the metaphor of Imam Shamil, Aboulela attempted to create awareness among Muslims and non-Muslims about Islam and Muslims' reality. In other words, she tried to condemn the criminal attacks of al-Qaeda members and those militant groups who target innocent civilians and call themselves jihadists. Such 'horrible' attacks, according to her, have only nourished the islamophobia phenomenon and othering in those societies.

Even though the two portraits, exposing the image of Muslims in the west and the antiterrorist voice were integrated, the former is used to serve the latter. Aboulela made it clear that the phenomenon of islamophobia is the ultimate outcome of the terrorist attacks by those who have misunderstood the concept of jihad in Islam. Such view is further emphasized at the end of the story through Aboulela's mouthpiece, Natasha, who admits that she:

wanted to compare Shamil's defeat and surrender, how he made peace with his enemies, with modern-day Islamic terrorism that promoted suicide bombings instead of accepting in Shamil's words, 'that martyrdom is Allah's prerogative to bestow'. How did this historical change in the very definition of jihad come about? (p. 324-5)

In her review of Aboulela's novel, Kate Braithwaite states that "by drawing parallels with history, this contemporary novel effectively shows how clarity has been lost in today's discussions of religious issues" (The Kindness of Enemies, 2017). Indeeed, it is interesting that Aboulela ends her story with the same idea with which she begins, the sharp contrast between Shamil's deeds and the current terrorist attacks under the pretext of Islamic jihad. Yet, in between, she clearly emphasized that those who target innocent civilians are mere terrorists and have distorted the image of Muslims in the world in general, and Muslim immigrants, in particular, and more importantly, have initiated the rise of the islamophobia phenomenon. II 


\section{Conclusion}

The Kindness of Enemies by Leila Aboulela united two stories, the history of Imam Shamil and the present story of Natasha Hussein. Although thay are set in different periods of time, yet, they are tightly related. Interestingly, the two stories had been skillfully integrated to illustrate the distorted image of Muslims and its relationship to the misconception of jihad/resistance.

The Novel, first, condemns the unjust social system that views Muslim immigrants as terrorists. In this sense, the author sharply ridicules the increasing negative attitudes like islamophobia, discrimination and racism against Muslims as those 'horrible' acts, to use the author's own words are performed only by a handful of people who neither represent Islam nor Muslims. Thus, Aboulela strongly rejects any attempt that connects Islam to terrorism. Another message is directed to those militant groups whom she made the butt of her criticism. She strictly blames them of violating the essence of jihad/resistance where she uses the figure of Imam Shamil as a metaphor to showcase the actual meaning of it. The death of Imam Shamil at al-Madinah after he performed Hajj is also symbolic as he died at the Sacred place. In contrast, those terrorists face a shameful death which could be a sign of their value in the eyes of God. In a nut shell, this novel confirms Aboulela's Islamic views, she uses her fiction as a medium to correct the distorted image of Muslims in the west. Instead of denying her "Muslim identity", as her heroine does, she "reconcile it with Britishness and debunk the association between Muslims and violence" (Hasan, p. 94).

\section{About the author}

Khaled Abkar Alkodimi is an assistant professor of English Language \& Literature, Imam University, Kingdom of Saudi Arabia. He got his PhD from University Putra Malaysia (UPM) in 2011. Dr. Alkodimi has participated in a number of international conferences and published a number of articles in different internationally scientific indexed journals on a wide range of topics. ORCID ID: https://orcid.org/0000-0003-4894-8223

\section{References}

Aboulela, L. (2005). Minaret. London: Bloomsbury.

Aboulela, L . (2015). The Kindness of Enemies. New York: Grove Press.

Al-Karawi, S. Taha \& Bahar, Ida Baizura. (2014). Negotiating the Veil and Identity in Leila Aboulela's Minaret. GEMA Online Journal of Language Studies. 14, (3): 255-268.

Alkodimi, K., A. (2019). New Perspectives in the Israel-Palestine Conflict: Righting the Wrong through metaphor in Mornings in Jenin. International Journal of Applied Linguistics and English Literature. 8, (6): 132-138.

Alzubaidi, D. (2016). Leila Aboulela discusses The Kindness of Enemies. The Arab Weekly. Retrieved June 30, 2020 from https://thearabweekly.com/leila-aboulela-discusseskindness- enemies.

Arab World English Journal for Translation \& Literary Studies 
Ancellin, K. (2009, July 8). Hybrid Identities of Characters in Muslim women fiction post 9-11. Presses Sorbonne Nouvelle. Retrieved July 10, 2020, http://trans.revues.org/344

Awad, Y. (2014). Writing from the Margins of the Nation: Leila Aboulela's Lyrics Alley. Arab World English journal. (2): 69-81.

Benguesmia, A. and Refice, Oum. (2019). Hybrid Identities and Muslim Faith in Leila Aboulela's Novels: Minaret and The Translator. MA. Diss. University of M' sila.

Bleich, E. (2012). Defining and Researching Islamophobia. Review of Middle East Studies. 46, (2): $179-188$.

Braithwaite, K. (2017). The Kindness of Enemies by Leila Aboulela. Book Review. Retrieved July 16, 2020 from https://www.bookbrowse.com/mag/reviews/index.cfm/book_number/3345/the-kindnessof-enemies

Carroll, R . (2016, January 3). A Muslim woman struggles with identity in the novel 'The Kindness of Enemies' by Leila Aboulela. Los Angeles Times. Retrieved July 8, 2020 from https://www.latimes.com/books/la-ca-jc-leila-aboulela-20160103-story.html

Flicker. (2020, April 17). Sudanese Novelist Leila Aboulela Becomes International Figure Through Religion, Alienation. Retrieved July 17, 2020 from https://fanack.com/sudan/faces/leila-aboulela/.

Frey, L., Botan, C., \& Kreps, G. (1999). Investigating communication: An introduction to research methods. (2nd ed.) Boston: Allyn \& Bacon.

Hasan, Md. M. (2015). Seeking Freedom in the "Third Space" of Diaspora: Muslim Women's Identity in Aboulela's Minaret and Janmohamed's Love in a Headscarf. Journal of Muslim Minority Affairs. 35. 1: 89-105.

Hassan, W. S. (2011). Immigrant Narratives: Orientalism and Cultural translation in Arab American and Arab British Literature. USA: Oxford University Press.

Khalifa, M. A. (2011). Muslim Women Write Back: Hybridity, Islam and the Quest for situations. $\mathrm{PhD}$. Diss. Cairo University.

Khrisat, A. (2018). The Image of the Oriental Muslim in Lord Byron's The Giaour. English Language and Literature Studies. 8, (3): 59-70.

Raina, S. A. (2009). Critical Content Analysis of Postcolonial Texts: Representations of Muslims within Children's and Adolescent Literature. PhD. Diss. The University of Arizona.

Ramji, R. (2016). Examining the Critical Role American Popular Film Continues to Play in Maintaining the Muslim Terrorist Image, Post 9/11. Journal of Religion \& Film. 20 (1). The 2015 International Conference on Religion and Film in Istanbul. 